\title{
TTR
}

Traduction, terminologie, re?daction

\section{Hebrew Translations of Palestinian Literature - from Total Denial to Partial Recognition}

\section{Hannah Amit-Kochavi}

Volume 13, numéro 1, 1er semestre 2000

Idéologie et traduction

Ideology and Translation

URI : https://id.erudit.org/iderudit/037393ar

DOI : https://doi.org/10.7202/037393ar

Aller au sommaire du numéro

Éditeur(s)

Association canadienne de traductologie

ISSN

0835-8443 (imprimé)

1708-2188 (numérique)

Découvrir la revue

Citer cet article

Amit-Kochavi, H. (2000). Hebrew Translations of Palestinian Literature - from Total Denial to Partial Recognition. TTR, 13(1), 53-80.

https://doi.org/10.7202/037393ar

\section{Résumé de l'article}

Traductions hébraïques d'oeuvres palestiniennes — de la dénégation totale à une reconnaissance partielle - Le présent article retrace les traductions en hébreu d'oeuvres palestiniennes émanant de Cisjordanie, de la bande de Gaza et de la diaspora palestinienne. Il explore également le passage graduel de la dénégation totale à une reconnaissance partielle de ces écrits au coeur du polysystème culturel hébreu.

L'introduction est suivie de trois parties. La première examine la position de la culture hébraïque israélienne face aux traductions d'oeuvres palestiniennes depuis les années 50, dans le contexte historique du conflit israélo-palestinien. La deuxième porte sur la publication des traductions de certaines oeuvres par quelques auteurs. Finalement, la dernière étudie les représentations théâtrales en hébreu d'adaptations d'oeuvres palestiniennes traduites.
Tous droits réservés @ C TTR: traduction, terminologie, rédaction — Les auteurs, 2000
Ce document est protégé par la loi sur le droit d'auteur. L’utilisation des services d'Érudit (y compris la reproduction) est assujettie à sa politique d'utilisation que vous pouvez consulter en ligne.

https://apropos.erudit.org/fr/usagers/politique-dutilisation/ 


\title{
Hebrew Translations of Palestinian Literature - from Total Denial to Partial Recognition
}

\author{
Hannah Amit-Kochavi
}

\section{Preface}

The present paper aims at describing the Hebrew translations of Palestinian literature and their political and cultural role within the Hebrew cultural polysystem (Even Zohar, 1990; forthcoming). First a definition of the source literature: Palestinian literature is one of numerous Arabic literatures (Elad-Bouskila, 1999, pp. 3-8). Unlike the situation with its Arabic counterparts, however, its affiliation is national rather than territorial - while Egyptian literature is that written in Egypt, Jordanian literature is that written in Jordan etc., up to the 1948 War, Palestinian literature, too, was territory-bound. Since then, however, due to the harsh historical and political circumstances that forced the Palestinians away from their land, it has become "a literature written by Palestinians" (ibid., p. 9) irrespective of their place of residence.

Palestinian literature may be subdivided into two branches: that written in the State of Israel as distinct from that written outside (ibid., p. 11). I have earlier discussed translations from the former category into Hebrew (Amit-Kochavi, 1996) and wish to discuss translations from the latter here. A number of Palestinian writers who grew up in Israel and later went into exile (e.g. Rashed Husein and Mahmoud Darwish) belong to both categories and are therefore included in both studies. Since very few works by Palestinian writers written prior to 1948 (Peled, 1982) have been 
translated into Hebrew, most of my discussion, with a few exceptions, will deal with works written after 1948 .

My data draws on a computerized inventory of translations of Arabic literature into Hebrew which I collected in Israeli university libraries and institutional archives (e.g. the Israeli Writers' Association Archive and Tel Aviv University Theatre Archive). They include titles published in book form as well as texts published in academic and literary magazines and in the literary and political sections of Israeli Hebrew dailies. The inventory includes 5445 items, 2000 of which are translation fragments published in both academic journals and journalistic sources. 447 (8.2\%) of the 3445 full texts are translations of Palestinian literature. These include 306 poems (14.5\% of the genre in the inventory); 62 short stories (3\%); 63 fragments (3\%) and 24 long works (14.6\%), including two novels (6.2\%); two short story anthologies $(4.6 \%)$, three novellas (75\%), four autobiographies (66\%), five poetry collections (17\%) and five theatrical works $(15.6 \%)$ adapted from other literary genres. These numbers demonstrate the relatively important position Palestinian literature occupies within the scant inventory of Hebrew translations from Arabic.

My discussion combines two foci: 1 . A general survey of the attitude of Israeli Hebrew culture to translations from Palestinian literature from the 1950s up to the present as reflected by the extent to which Palestinian works have been translated, where they were published, and critical reviews against the changing political background. 2. A detailed analysis of significant case-studies.

\section{Israeli Jewish attitudes towards translations of Palestinian literature from the 1950s, and their historical background}

The attitude of Israeli Jewish culture to translations from Arabic literatures, including Palestinan literature, into Hebrew has been directly affected by the Jewish-Arab (later, Israeli-Arab) conflict. The following are some particularly significant historical landmarks:

- From the advent of Zionism in Palestine (1882) up to the establishment of the state of Israel (1948) Palestinian Arabs 
constituted a majority as against the Jewish minority. The two different communities maintained separate socio-economic systems (Horrowitz \& Lisak, 1986). With very few political and cultural exceptions the relations between them reflected their constant struggle over territory, work, and control (Gorny, 1985) in a country under foreign (first Turkish, later British) rule. Jewish Hebrew culture, including literature, drama, the arts, dance and both canonical and folk music stereotypically depicted the Arab from two opposite points of view - on the one hand he was perceived through Romantic stereotypes of European origin as a sexually attractive "wild savage", an image reinforced by seeing him both as the historical prototype of the Biblical ancestors of the Jews (Nir, 1985) and as a contemporary model for the Jewish settlers in Palestine. On the other, he was perceived as a bloodthirsty ruthless enemy wishing to annihilate the Jews returning to their ancient homeland 2 . These stereotypes both prevented Hebrew culture from viewing Arabs as individual human beings, and some of them still prevail.

- The 1948 war made most of the Arab population of Palestine leave for the neighbouring Arab countries (Said 1978, 1993; Morris, 1991). This created a mass of Palestinian refugees whom Israel ignored and the hosting Arab countries refused to accept as ordinary citizens. The incessant trauma of exile and life in humiliating conditions while pining for the old homeland constitutes the thematic backbone of Palestinian literature much more than in any other Arab literature.

- The 1948 war completely severed Israel from the Arab countries, turning the Arab into an ephemeral figure for most Israelis, thus further reinforcing the stereotypical view of the Arab as a dangerous enemy in Hebrew culture. This view was reflected by children's

\footnotetext{
1 For a select bibliography see Bahat 1972; Eshel 1981; Domb 1982; Ben Ezer 1992; Orian 1996.

2 Arab women were mostly referred to in Israeli Hebrew literature and drama as sexual objects. For the depiction of both Arab men and women in visual art, see Zalmona and Manor-Friedman's catalogue of 100 years of Jewish visual art in Palestine, later Israel (1998).
} 
literature (Cohen, 1985) that strongly affects young readers and usually serves the predominant values of the culture it pertains to (Shavit, 1986).

- The armed conquest of the West Bank and Gazza Strip by Israel in 1967 renewed direct Israeli contact with Palestinian Arabs, bringing back the long-absent Arab. The long ignored Arab refugee problem now reemerged as one requiring a political solution. Israeli military occupation of the Territories has involved blatant personal and collective oppression. Some Israeli Jewish individuals and groups, however, have demonstrated a growing interest in and empathy with the Palestinians, expressed in works of literature, drama (Orian, 1996), cinema (Shohat, 1991) and the visual arts (Zalmona \& Friedman-Manor, 1998).

- The first Oslo Agreement signed in 1993 between Israel and the Palestinian Authority was the culmination of a gradual process of mutual recognition. Discussions about the size and political identity of the Palestinian entity are still going on and the relationship between Israel and the Palestinians remains the most complicated of all Israeli-Arab contacts. A few politicians and writers on both sides had met prior to the Oslo Agreement, when such encounters were banned by Israeli law. Some meetings included mutual reading of bilateral translations of literary works. This practice drew on the naive mutual belief that literary translation could bridge the deep cultural gap between Arabs and Jews, affect readers' attitudes, contribute to Arab-Jewish coexistence and even change the political situation.

All of these historical landmarks have directly affected the translation of Arabic literature into Hebrew and that of Palestinian literature in particular. The most remarkable change in the case of Palestinian literature followed the Six Days' War (1967), when a growing Israeli interest in the Palestinians was reflected by a considerable increase in translation activity during the 1970 s and 1980s. Since most Israeli Jews have no command of the Arabic language and culture (Landau, 1961; Yonai, 1992; Kinberg and Talmon, 1994) most Israeli Jews fail to distinguish between Israeli Arabs, Palestinians, Egyptians etc. All Arabic literatures are therefore perceived by non-expert Hebrew readers as a 
single entity. That is why the very act of translating a work from any Arabic literature into Hebrew is considered as siding with the Palestinian issue. Thus, for example, special numbers and sections of Hebrew literary magazines have been published in order to express the editors' or translators' protest against the continued occupation of the Territories or against the Lebanon war through translations from various Arabic literatures that were not necessarily those geopolitically or thematically relevant.

\section{Palestinian writers, works and publications in Hebrew translation}

2.1 Publication in dailies, academic and literary magazines and by publishing houses

The examination of where the translations were published best demonstrates changes in their position vis à vis Israeli Hebrew culture. The earliest translations were published during the 1960s when all Arabs, Israeli or otherwise, were perceived by Israel as dangerous, and all so-called "Arab affairs", including the translation of Arabic literature(!), lay almost exclusively in the hands of Israeli security forces. Thus some of the first Hebrew translations from the works of the talented poets Mahmoud Darwish and Rashed Husein by Avraham Yinon were published in official collections of Israeli Arabic literature (1962-1966) especially prepared for the Prime Minister's Office. These collections later served Yinon in writing two articles about Israeli Arabic literature (1965; 1966) for Hamizrach Hehadash [= New Orient], the Israeli Oriental Society periodical published by the Hebrew University of Jerusalem. Palestinian literature thus became less marginal (Even Zohar, 1990), moving from publication in a governmental framework intended for a small professional target readership to publication in an academic framework addressing scholars, students and the general public. With regard to the first translations, what was still considered by Hebrew culture as unacceptable for readers of literature was considered appropriate for "Arab Affairs" academic experts. Translations of Palestinian literature thus served the purpose of "Know thy enemy!" rather than that of "Know thy neighbour!".

There were, however, a few exceptions to this rule - translations of Palestinian literature were published by newspapers which did not 
embrace the general anti-Arab consensus but supported Jewish-Arab coexistence. Thus, poems by Rashed Husein were translated by Sasson Somekh, a Jewish immigrant poet from Baghdad (1951) who later became a prominent scholar of modern Arabic literature as well as the most prolific translator of Arabic poetry into Hebrew. From 1957 on he published some of his translations in Qol Ha'am [= the voice of the Nation], the organ of Maki, the Israeli communist party, at the time the only Israeli party to give Arabs equal standing and cultural support. Later (1958) his translations were "promoted" to the privately-owned daily $H a^{\prime}$ aretz whose literary editor at the time was Binyamin Tamuz. Tamuz was a Hebrew prose writer whose work expressed nostalgic longing for the old Palestine he had grown up in and the friendships and rivalries between him and his Arab childhood playmates. He was a member of a pioneering group of Israeli Hebrew writers who at the time organized the first recorded Jewish-Arab writers meeting that included the reading and heated discussion of translations of the Arab participants' works. Although participants on both sides included mainstream writers whose political views supported Jewish-Arab equality, the bitter complaint against land confiscation and inequality expressed by the Arabic poems read in Somekh's Hebrew translation was more than the Jewish writers could stomach, as expressed later in their written reactions published by the Hebrew press. Consequently, no further encounters took place for almost another two decades (for a detailed report of the event and its aftermath see Somekh, 1999).

Later publication of translations of Palestinian poems demonstrated two opposing trends with regard to publication policy: official and semi-official publications, e.g. by the Israeli Writers' Association and the Histadrut, the Israeli Trade Union that ran a number of cultural institutions, presented a sugar-coated version of mutual Jewish-Arab understanding, advocating peace and equality that was preached rather than practiced. Thus Yona David, the secretary of the Hebrew Writers' Union at the time, included a poem by Rashed Husein in an anthology of Hebrew literature (1959) in order to demonstrate the integration of the Arab population in young Israel. Husein was probably chosen thanks to his much acclaimed translation into Arabic of poems by Bialik, the national Zionist poet, the only Arabic text published by the short-lived but prestigious translation series of the Oriental Studies Institute of the Hebrew University of Jerusalem (1966). The chosen text, 
"To the Infants of my Country", advocated mutual love and peace (David, 1959, pp. 257-258). The contrasting trend allowed for the frank expression of Israeli Arabs' hard feelings due to their exclusion from the exclusively Zionist Israeli entity. Another poem by Husein published earlier in Ha'aretz had voiced his complaint that the doors of Kibbutz and Moshav, both Israeli Jewish settlement models, shut him out. How, then, asked Husein, was he expected to praise Zionism that made no room for him? (Ha'aretz 10.10.58).

These contradictory texts were later recycled in school textbooks. The same progress from a limited target readership to a larger one described above was at work here. The translated poems were first included in the school textbook Eshnav [ $=$ Small Window], a reader published as early as 1970 in the aftermath of the 1967 war, that was especially prepared for Hashomaer ha-Tza'ir, a Kibbutz left-wing movement that preached Jewish-Arab coexistence. Ha-Darekh'la-Shalom [ = The Road to Peace], a bilingual reader intended for the general educational system compiled by the Israeli Ministry of Education and Culture, was published as late as 1994 to commemorate the first Oslo agreement. In both cases the direct link between political circumstances and the publication of translations of Palestinian literature into Hebrew is clear.

1970 was a major landmark in the infiltration of translated Palestinian literature into Hebrew culture. In addition to Eshnav, intended for a small sector of Israeli Jewish schoolchildren, literary translation from Arabic literatures in general and from Palestinian literature in particular gained considerable momentum from this year on with the pioneering publication of several important Palestinian texts in Israeli Hebrew literary magazines. A special number of Qeshet [ = Bow/Rainbow] dealt with Arabic literature in the aftermath of the '67 defeat (Qeshet 47, 1970). Qeshet (1958-1976) was a prestigious privately-owned magazine edited by writer and translator Aharon Amir. Amir was a member of a minor cultural movement, the Kanaanites, who wanted Israeli Jews to detach themselves from diaspora Jews and get integrated into Mediterranean culture in order to continue the general ancient local tradition rather than their own particular historical national one. Qeshet therefore extensively published translations from Arabic and essays about the Middle East and the Levant as part of this unique policy 
that stood in direct contrast to the segregational Israeli Jewish culture predominant at the time.

All the literary texts included in that special number of Qeshet were selected and translated by Sasson Somekh, the leading translator and guest editor of this and many similar ventures in Israeli Hebrew magazines since the late 1950s. The texts strongly criticized the weakness of the Arab world presented as responsible for its shameful military defeat in 1967. Writers included three Palestinians: Mu'een Bseeso's poem "The Poem and the Dagger" expressed bitter mockery of Arab military presumptions (e.g. "for the price of frogs who will purchase/ these drums?" ibid. p. 6); "June Memories", Rashad Abu Shawar's short story, expressed the frustration of a Palestinian, a refugee since 1948, living at the Jericho refugee camp, and forced in June 1967 to escape from the Israeli-occupied West Bank, who eventually opts for armed resistance.

The work of Palestinian poetess Fadwah Tuqan was described in the same number of Qeshet in a pioneering article by Somekh ("Lev Isha min ha-Mizrah" [= An Oriental Woman's Heart], ibid, pp. 112-123) where he quoted some of her poems in his own translation. Somekh pointed out Tuqan's abrupt transition from lyrical poetry to "mobilized" political poetry following the 1967 war, attributing this change to social pressure exerted on her as well as to her fear of losing her central position within her culture if she refrained from joining the patriotic poetic trend. The article was written in strict academic format despite its publication in a literary magazine. In this Somekh followed the practice of other Israeli Arabic literature scholars who adhere to the academic model ${ }^{3}$ even when writing for a general readership since the understanding of all "Arab affairs", literary ones included, is considered by Israeli Jews, most of

3 The academic model includes the extensive use of academic references, footnotes and translation fragments used to prove a point. It often includes prefaces or afterwords providing a broad spectrum of the subject under discussion that outstrips the scope of the subject under discussion. Thus translations of a particular literary work from Arabic into Hebrew may include an encapsulated history of the author's work or even of the literary school or genre he/she adheres to. 
whom are ignorant of them, as the prerogative of a small elite, military, academic, or both, using its own professional jargon.

Somekh sympathetically referred to the poems as "lamentations over the fate of the robbed homeland and the refugee tragedy" (ibid, p. 114), pointing out that Tuqan's political poems were "militant poetry that constitutes a reaction to reality" (ibid, p. 120). In his only negative comment Somekh referred to a poem where Tuqan expressed a wish to devour Israeli soldiers' livers 4 as "a poem full of hatred".

For the first time in Hebrew culture this special issue of Qeshet legitimized the presentation of Palestinian literature to Hebrew readers. That issue also included translations of other Arabic literatures Egyptian, Syrian, Lebanese and Iraqi - presenting Palestinian literature as one of several Arabic literatures rather than as a separate cultural entity.

Another major contribution to Hebrew translations of Palestinian literature was made by Shimon Ballas, who, like Somekh, was an Iraqi Jewish immigrant deeply rooted in both Arabic and Hebrew cultures, a writer and a scholar. Ballas published two separate volumes - an academic one, Ha-Sifrut ha-'Arvit be-Tzel ha-Milhamah [= Arabic Literature under the Shadow of War] published by Ofaqim library', and a literary one, the anthology Sippurim Palestinyim [= Palestinian Stories] published by

4 Tuqan made metaphorical use of a famous episode of early Islam where a respectable woman devoured the liver of Hamza, the Prophet Muhammed's uncle, after he died on the battlefield. She later approached Muhammed, asking to be converted to Islam, which wipes away all prior sins. Once converted she uncovered her face and admitted her real identity, telling the prophet that had his uncle had a number of livers she would have devoured all of them to avenge the blood of her husband and sons killed by Hamza earlier. She was since known as "Aakilat al-Akbad" (the liver eater).

5 Ofaqim library publishes books of academic and intellectual interest to the general public and is highly prestigious. It is a branch of Am Oved publishing house affiliated with the Histadrut, one of Israel's central establishment publishing houses. 
Eqqed6, the first anthology of Palestinian short stories translated into Hebrew.

Ballas' study included texts depicting the Palestinian tragedy and reflecting both the 1948 and 1967 disasters. Writers included Palestinians, Egyptians, Syrians and Lebanese. The stories described Palestinian life before and after exile, dwelling on the psychological effects of pining, the humiliation involved in refugee life, and the despair that drives people to take up arms against the Israeli Jewish enemy.

The book was a pioneering Israeli Jewish study of Palestinian literature. The translated fragments included in the study drew a broad picture of Palestinian literature and themes otherwise out of Hebrew readers' reach. Even today, almost 30 years later, most of the works quoted by Ballas are not yet available in Hebrew translation.

Ballas' short story anthology drew directly on his research. It included 14 stories by nine writers. His introduction provided a historical survey of Palestinian literature in general and the work of several central writers in particular. Ballas pointed out the transition from what he considered as writing with no local emphasis prior to 1948 to the longing for lost Palestine after 1948, the consolidation of national identity of a nation torn away from its land and the national struggle over both the Palestinian homeland and Arab unity. Ballas' attitude towards the Palestinian issue was complex - he combined facts drawing on his own research with emotional expressions typical of Israeli Jewish consensus at the time, equating the Palestinians' wish to liberate their homeland with "the liquidation of the State of Israel" (ibid, p.15). Ballas, however, also demonstrated empathy for the "tragic [situation] of a miserable, betrayed, helpless nation, frightened and devoid of national self-awareness, licking its wounds while waiting to be saved by some Arab ruler or other" (ibid, p. 17). He concluded with a statement extremely daring at the time, saying that by means of that anthology he wished "to make Hebrew readers

6 Eqqed is a small private publishing house that was highly popular at the time for its varied literary texts, including modern Hebrew poetry and translations of European poetry (French, Italian, Spanish, etc.) The volume under discussion was one of the few prose texts published by Eqqed and is its only translation from Arabic. 
familiar with the psychology, life and mind of the Palestinian, who, though still separated from us by high walls of estrangement and enmity, is our equal partner on this land and under the light blue sky above our heads" [the emphasis is mine, HAK] (ibid, p.18).

Another significant publication of translated Palestinian literature in 1970 was Ofeq [= Horizon], a short-lived (1970-1972) magazine edited by poet Yossi Gamzu who wished to propagate dialogue between different opinions within Israeli society. Like most editors of Israeli Hebrew press Gamzu could not read Arabic. Like others who took an interest in Arabic literature he used Sasson Somekh as an expert. Somekh translated two poems by Fadwah Tuqan, one lyrical and the other political, describing the conquest of Nablus, the poetess' city, in 1967, for the first number of $O f e q(1970)$. This was a direct continuation of his article published earlier by Qeshet. However, unlike Qeshet, which published translations from Arabic together with translations from other languages, Ofeq "segregated" translations from Arabic in a special section, "A look at the Arab world", as distinct from another one, "A look at world literature" where translations from Russian, Turkish, Greek and English were published. Devoting a special section to Arabic literature was intended as an act of corrective discrimination emphasizing the special interest taken by the periodical in this subject. Separating it from so-called world literature, however, was an act of cultural ghettoization, adding another block to the narrow road of translations of Palestinian literature into Hebrew paved with good intentions.

The second number of Ofeq (1972) included a fragment of the novella, Returning to Haifa by Ghassan Kanafani translated by Shmuel Regulant, and accompanied by an article by Somekh about the writer and his work (ibid, pp. 145-155). The novella is a key work in Palestinian exile literature. It describes the tragic visit of the refugee couple S'aeed and Safiyyah back after 1967 to see Haifa where they had left their baby son during their hasty escape in 1948. They find their old house unchanged but inhabited by Miriam, a Jewish Holocaust survivor and war widow who found and adopted their son, now an Israeli soldier. In the encounter between them the respective suffering of the protagonists is presented as equally tragic by Kanafani, himself a refugee. The couple's son, once called by the Arab name Khaldoon, now called by the Hebrew name Dov, chooses to stay on the Israeli side. In order to balance this 
choice S'aeed tells his wife on their way home that he hopes their other son, Khaled, will join a Palestinian military organization, implying that this is the only way left now. The fragment of the novella published in Ofeq describes the encounter between the son and his real parents. Two other fragments of the same novella were later published in other literary periodicals (Moznayim, $\mathrm{n}^{\circ}$ 57, 1983, pp.12-14; Mifgash-Liqaa $\mathrm{n}^{\mathrm{os}} 7-8$, 1987, pp. 36-37). The translation of the full text, however, is to be published in a forthcoming anthology of Palestinian prose 28 years after the publication of the first fragment (!).

This fragmented presentation is common in publications of translations of Palestinian literature as well as all other Arabic literature. It is much easier to have short texts or parts of long ones published in magazines than to have the full text published in book form, for the following reasons: it is faster and cheaper to translate and publish poems, short stories and fragments of novels than to translate long novels and plays; translators from Arabic into Hebrew translate part-time and can seldom spare the time for a long text; periodicals and literary magazines that publish translations of Palestinian literature as a part of a particular issue run a smaller political and economic risk than publishing houses that publish long Palestinian texts.

\subsection{Translating and publishing novels and autobiographies}

The special preference given to translations from Palestinian literature into Hebrew ( 9 out of a total of 34, namely $26 \%$ ) is best reflected in the relatively large number of long texts (novellas, novels and autobiographies) translated and published from the mid 1970s on. Before going into a detailed discussion of some of the texts and publishing houses, as well as an explanation of this phenomenon, a full list of the texts may prove helpful:

1976 - Sahar Khaleefah, The Cactus, translated by Salmaan Msalhah, Galileo Publishing House, Jerusalem. (novel)

1978 - Ghassan Kanafani, Men in the Sun and What is Left to You, translated by Daniella Brafmann and Yani Damianos, Mifras Publishing House, Jerusalem. (two novellas in a single volume)

1985 - Ghassan Kanafani, Returning to Haifa, translated by Fortuna Shapiro, M. A. thesis, Department of Communication, the Hebrew 
University of Jerusalem. [never published] (novella) 1987 - Sahar Khaleefah, The Sunflower, translated by Rahel Halabe, Mifras Publishing House, Jerusalem. (novel) 1989 - Mahmoud Darwish, Reminiscences of Forgetfulness, Time: Beirut, Place:August, translated by Salmaan Msalhah, Shoken Publishing House, Jerusalem \& Tel Aviv. (autobiographical memoire) 1990 - Khaleel al-Sakakeeni, That's what I am, Gentlemen! Out of Khaleel al-Sakakeeni's Journals, translated by Gideon Shiloh, Keter Publishing House, Jerusalem. (journals)

1991 - Mahmoud Darwish and Sameeh el-Qasem, The Two Halves of the Orange, translated by Hannah Amit-Kochavi, Mifras Publishing House, Tel Aviv. (poetic correspondence)

1993 - Fadwah Tuqan, A Journey up the Mountain, translated by Rahel Halabe, Mifras Publishing House, Tel Aviv. (autobiography)

To be published - Ghassan Kanafani, Returning to Haifa, translated by Gideon Shiloh, Hed Artzi Publishing House, Tel Aviv. (novella)

The relative abundance of translations of Palestinian novels may be explained by the fact that most of them were published by small independent publishing houses outside of Israeli Jewish consensus. Publication of the long translations thus mostly took place at the margin of Israeli Hebrew culture and the few cases where it occurred closer to the center were one-time events due to special circumstances.

There was, however, one case of relative progress towards the centre when The Cactus was published both in Arabic (1975) and in the Hebrew translation of Salmaan Msalhah (1978) by Galileo, a small Arabic publishing house in East Jerusalem, whereas Khaleefah's next novel, The Sunflower, was published by Mifras (1987), a small fringe Israeli Jewish publisher.

Mifras was a privately-owned radical publishing house (1978-1993) established in order to introduce Hebrew readers to texts dealing with issues outside Israeli political and cultural consensus at the time. All nine literary titles it published were translations from Arabic, (!) including five Palestinian titles (55\%!), the largest number of long translations from Arabic ever published by any Israeli publishing house, three of which were by woman writers. Palestinian suffering was depicted as follows: the refugee problem was described in Ghassan Kanafani's Men 
in the Sun and What's Left to You. The complex situation of Israeli Arabs was described in the novel The Pessoptimist by Israeli Arab Emile Habibi (1984) (for details concerning Habibi's special position in Israeli Hebrew culture, see Amit-Kochavi, 1996); the Palestinian identity conflict was demonstrated by The Two Halves of the Orange, a literary correspondence between two major Palestinian poets who grew up in Israel - Mahmoud Darwish, who left Israel (1970), and his friend and colleague Samih el-Qasem, who stayed; Palestinian resistance to the Israeli conquest of the West Bank and Gazza Strip was described in the writing of two Palestinian woman writers - Sahar Khaleefah (1987) and Fadwah Tuqan (1993). All of these works were published by writers whose position was prominent in their source literature and who played active roles in the Palestinian struggle for self-identity and freedom.

One of the main contributions by Mifras to Israeli Hebrew culture consists in the courageous pioneering publication of texts not acceptable to central publishing houses due to their contents. A case in point is The Two Halves of the Orange (1993) by Darwish and el-Qasem: numerous translations of the former's poems and a few of the latter's had been published in Hebrew literary magazines and a volume of Darwish's Reminiscences of Forgetfulness (1989) had been published by Shoken?, a private prestigious publishing house. Darwish's poetic correspondence with el-Qasem was suggested for publication by Ami Elad, a prominent modern Arabic scholar and translator, to Keter Publishing House where he was serving as editor of Bidayat [= Beginnings], a successful series of Arabic literary titles. The book was rejected by Keter due to the political content of the text and Mifras volunteered to publish it.

The Two Halves of the Orange, symbolizing divided Palestine, depicted the two complementary sides of the Palestinian coin - one represented by Darwish, a self-imposed exile (1970) and the other represented by el-Qasem who chose to stay in Israel.

7 Shoken was established in the early 1920 s in Germany by Zalman Shoken, businessman and supporter of Jewish studies and Hebrew literature, who later moved his various cultural activities to Palestine where he established the private daily $\mathrm{Ha}$ 'aretz still owned and run by his family. 
Keter's refusal to publish this particular title may seem strange as it had earlier published in Bidayat the journals of Palestinian educator and public figure Khaleel al-Sakakeeni who had lived in Jerusalem up to his forced exile in 1948. Sakakeeni was an Arab patriot who considered Jewish settlement in Palestine perilous to Palestinian aspirations and his journals demonstrate his fear and concern at the deepening roots struck by Zionism in Palestine, and describe his personal involvement in Palestinian public life. At the same time he was on good terms with several pro-Arab Jewish leaders whom he taught Arabic. Keter probably published the journals thanks to an episode where Jewish merchant and poet Alter Lewine, Sakakeeni's one-time pupil, sought shelter in his house from the Turkish police. The latter complied in accordance with traditional Arab hospitality and eventually they were both captured and exiled to Damascus where they were imprisoned together. In this case, then, a single pro-Jewish episode made possible the publication of a Palestinian patriotic text, that would otherwise have been considered highly offensive to Zionism.

\subsubsection{The reactions of Israeli Jewish critics to Palestinian long texts}

The reception of Khaleefah's and Tuqan's feminist texts by Israeli Jewish critics was ambivalent. It oscillated between admiration for the courage demonstrated by heroines confronting masculine oppression in their own society and shock at the anti-Israeli views expressed in Khaleefah's novels. Much was made of a short pro-Israeli passage where Rafeef, a heroine of The Sunflower, an editor in an East Jerusalem magazine, expresses her wish to meet Israeli colleagues and talk to them. The only overt anti-Israeli statement in the novel is at its conclusion where Sa'diyyah, whose house is demolished by Israeli soldiers, tells her elder son to throw stones at them in revenge. This premonition of the Intifadah, however, by and large escaped the attention of Israeli Jewish critics.

Tuqan (1917- ), a generation older than Khaleefah (1944- ), concentrates in her autobiography on her double predicament as an Arab woman. First, as a young girl with a gift for poetry and scholarly aspirations, she was forced by her father to give up school early. Later, her father demanded that she replace her brother, poet and politician 
Ibraheem Tuqan, in both of these roles following his early death. Tuqan bitterly protests against these impossible contradictory demands.

Israeli critics readily accepted this description that perfectly fit their negative stereotypical view of Arab society. They chose to ignore the last part of Tuqan's autobiography, taken out of her personal diary, where she describes her shocked silence following the Israeli conquest of her hometown Nablus and her subsequent decision to dedicate her talent from that time on to her people's struggle.

Hebrew critics, then, applauded the personal aspects of Khaleefah's and Tuqan's writing, ignoring its political aspects in stark contrast to Khaleefah's consistent concern with Israeli occupation in her literary work and to Tuqan's prominent role as the Palestinian national poetess.

Ghassan Kanafani's novellas Men in the Sun and What's Left to You had appalled Hebrew critics some years earlier (1978-1979). In his introduction to the book, Shimon Ballas had expressed the naive belief that literary translations could solve political conflict:

There is no better way than literature to reflect both private and public life and nothing is more efficient than literature in order to reach mutual understanding between nations. Kanafani, the writer and enemy who died young, proved this through his literary work, thus perhaps undermining its basic assumption that an understanding between us and the Palestinians is practically impossible (ibid, p. 12).

Reviews by two literary critics, whose personal political positions were pro-Palestinian ${ }^{8}$, stood in direct opposition to this optimistic view. While the novellas divided the responsibility for the refugee plight between Israel, that started the problem, and the Arab countries that failed to solve

\footnotetext{
8 Ilana Hammermann in particular is famous for her active protest against Israeli occupation of the Territories. She has signed numerous anti-occupation petitions, participated in demonstrations, openly met Palestinian intellectuals in Gazza strip and co-edited a book of IDF (Israeli Defence Forces) soldiers' testimonies condemning Israeli cruelty during the Intifadah.
} 
it, both critics failed to see this balance, exclusively expressing their own fear of Palestinian anger and despair.

Ilana Hammermann, a literary editor and translator of German and French literature, questioned Ballas' optimism, saying: "We' 11 have to specify exactly who is intended when speaking of [a dialogue] 'between us and the Palestinians'. Which ones of us? Which ones of them?" (Ha'aretz 24.5.79). Shim'on Sandbank, professor of comparative literature at the Hebrew University and translator of English and German poetry into Hebrew went even further. He expressed deep shock at the anti-Israeli contents of the novellas and was appalled by the despair and violence they expressed, doubting the possibility of any dialogue between Israel and the Palestinians. To prove his point he made a meticulous analysis of the novellas where he claimed to have discovered strong animism with regard to both the sun, depicted as a destructive force of destiny, and the land. Sandbank described the Palestinians' erotic attitude towards the land and how its loss represented the loss of national pride and the loss of Arab virile pride symbolized by the sexual impotence of one of the male protagonists through an injury in a battle against Israel. This reminded him of parallel strong emotions on the part of those "captivated by lust for the land" on the Israeli side. He concluded by saying that such strong emotions on both sides ruled out any possibility of peace and understanding between them (Davar, 10.11.78)9.

2.3 Publication and dissemination of translated Palestinian literature by Israeli cultural institutions

In addition to the publication of translations of Arabic literature in literary magazines, literary sections of dailies, and by publishing houses, translations were sometimes sponsored by cultural institutions supporting Jewish-Arab mutual understanding and peace education. Thus, for example, the Van Leer Institute of Jerusalem published an anthology of 21 translated Arabic short stories, A Place upon this Earth (1986/1995)

9 The daily Davar (1925-1996) was the official organ of the Histadrut trade union voicing the opinions of the predominant socialistic Mapai party that enjoyed enormous political and cultural power over Israeli Jewish institutions both prior to the establishment of the state of Israel and during its decisive formative years. It was closed down as a result of the total decline of that power. 
intended as a highschool literary reader, including a single Palestinian story, "Land of the Sad Oranges" translated by Shimon Ballas and already published in his anthology discussed above (for further details see Amit-Kochavi 1999).

The following is the detailed case-study of a cultural institution which, although it professed universal cultural aims, particularly sought to promote Israeli-Palestinian cultural contact through literary translation.

Mishkenot Sha'nanim, a Jerusalem artist guesthouse (inaugurated 1973) is a prestigious cultural institution that hosts musical and literary events and workshops, invites prominent musicians and writers and organizes both public international poetry festivals and local cultural events. Two of these activities have involved translations of Palestinian literature. One was public - Mishkenot international poetry festivals $(1990 ; 1993 ; 1997 ; 1999)$ have all included Arabic poetry in general and Palestinian poetry in particular in their poetry reading events and anthologies. The other was private, consisting of encounters between Israeli Jewish and Arab writers and their counterparts from the West Bank and Gazza Strip (1992-1995). These events, including long weekends at the institution's lovely guesthouse, were kept secret in order to protect both the professed political neutrality of Mishkenot and the personal safety of the Palestinian participants.

The festivals were prestigious cultural events covered by the media, broadcast on literary radio programmes and accompanied by special theatrical programmes and anthologies. Arab poets were chosen by the festival advisory board, composed of Mishkenot staff and Israeli Hebrew writers according to two criteria - geopolitical affiliation, in an attempt to get as broad a spectrum of the Arab world as possible, and the poets' readiness to participate in a cultural event taking place in Israel, in a building overlooking the ancient wall of Israeli-occupied East Jerusalem. Consequently, Arab participants included some long-time exiles from Iraq and Yemen living in Western countries to compensate for the absence of poets from enemy countries.

Arabic was given priority over other languages - Arab poets constituted some $15 \%$ of the participants and about $25 \%$ of non-Hebrew writers. Palestinian poets often participated: in 1990 - three out of nine 
Arab poets; in 1993 - two out of six ; in 1997 - one out of four. In 1999 all the Arab poets, Israeli or otherwise, invited to the festival blatantly refused to attend since the opening night, June $5^{\text {th }}$, coincided with the opening date of both the 1967 and 1982 wars. While the poets from Egypt, Jordan and the Palestinian Authority boycotted the festival, the Israeli Arab poets refused to attend in person but did not withdraw their poems from the festival anthology. Thus a political oversight on the organizers' part did serious damage to a rare example of successful Israeli-Arab cultural cooperation.

The financial and cultural independence of Mishkenot was reflected in the contents of the Palestinian poems read and published during the first three festivals, most of which expressed strong resentment for Israeli oppression. Palestinian poems were published in the festival anthologies in a single sequence with all other languages in order to emphasize the universality and equality symbolized by the international festival. On one occasion Palestinian poetry was given special preference - the 1993 festival included a special reading of Hebrew and Arabic poems accompanied by a bilingual programme in a festive event attended by the Mayor of Jerusalem and the Israeli Minister of Culture. This was done in celebration of the first Oslo Agreement that had immediately preceded the festival.

Mishkenot Jewish-Arab secret writer encounters were intended to promote intercultural contact in order to alleviate mutual mistrust and misunderstanding. Their aim, then, combined art and politics. Participants were therefore chosen both according to the literary merit of their work and their belief in such encounters. Each meeting had a particular focus relevant to the Jewish-Arab conflict, e.g. affiliation to one's homeland as opposed to exile. Literary texts by both participants and other writers were read and discussed in Arabic, Hebrew and English. Although Arab participants included only Arabs from Israel, the West Bank and Gazza Strip, Arabic texts included Palestinian and Israeli Arab texts as well as Egyptian and classical Arabic texts which occupy a high position in Arabic culture and Israeli university Arabic departments. Their inclusion functioned as a common denominator for both sides of the dialogue.

Much money and energy were invested in the encounters by Mishkenot. But the limited distribution of the translations, most of which 
were new, among the participants only, was a waste in terms of the small Hebrew inventory of translations from Arabic into Hebrew and vice versa and the secrecy of the encounters prevented them from having any public impact.

\section{Hebrew stage performances of translated Palestinian literary works}

Out of the 33 plays translated from Arabic into Hebrew or adapted for stage performance from prose and poetry translations, five were Palestinian. Like all translations from Arabic, Palestinian plays, too, were performed in fringe theatrical frameworks, as all establishment theatres refused to perform plays translated from Arabic, for fear of their political content or due to the Western orientation of the theatres and their cultural condescension towards Arabic culture. The theatre, then, proved to be a more conservative and less open-minded cultural framework than literary publication, although a number of the people involved in Israeli theatrical activity, including both artists and administrators, publicly professed left-wing opinions and were politically active in pro-Arab protests.

Three performances of Palestinian theatrical works took place in the academic world, a safe place for experimentation, and were carried out by Israeli Arab theatre students as their graduation assignments. They all took place at Tel Aviv University, the staff of whose faculty of humanities is supposedly mainly left-wing, while other Israeli theatre schools, both academic and private, avoided such experiments, abiding by the tacit policy of the theatres where their graduates sought acceptance.

A House Divided by Tawfeeq Fayyad, born in Palestine in 1939 and exiled from Israel in 1974, was translated and performed by student Rateb 'Awawdah and directed by fringe director Yizhaq Ne'eman (1981) in close Jewish-Arab cooperation typical of the performance of Arabic plays on the Hebrew-speaking stage (Horrowitz 1993; Orian 1996; Amit-Kochavi 1996; 1999). It was later publicly performed in the small Tel Aviv auditorium Zawta owned by the left-wing Kibbutz movement Ha-shomer ha-Zai'r which upholds Jewish-Arab coexistence. A similar venture carried out in the same year (1981) was the stage adaptation of Kanafani's novella Men in the Sun by director student Fuwad 'Awad (1981) from the available Hebrew translation (1978). Reminiscences of Forgetfulness, Mahmoud Darwish's literary diary written during the 
Israeli siege of Beirut, was also adapted for stage performance from the available Hebrew translation (1989). Actor 'Imaad Jabareen later performed it under the auspices of the fringe Kibbutz Theatre. In all three cases Israeli Arab students chose to declare their artistic and national identity through texts expressing the plight of their exiled counterparts through performance in Hebrew translation to Hebrew-speaking audiences, and were supported by Israeli Jewish institutions. While Tel Aviv University is strong and prestigious, the two theatres that adopted these projects were small and marginal and all three performances reached small audiences.

Overt Jewish-Arab cooperation was demonstrated in the case of Newe Zedeq Theatrical group, an experimental group of actors working in Tel Aviv. They had preceded Jabareen in protesting against the Lebanon War as soon as it broke out (1982) in a documentary play They-Hum [="They" in Hebrew and Arabic] written by the group and directed by American Frank Cheney. The group included equal numbers of Jewish and Arab actors who tried to understand each other's fear and anguish through an exchange of roles - Jews played the Arab roles of Lebanese and Palestinians, while Arabs played the Jewish roles of settlers in the Territories. Performances were followed by open discussions with the Israeli Jewish audience, a common practice in Israeli fringe theatre.

Last but not least, a single attempt by a well-known Jewish actor to perform Palestinian texts on the Hebrew-speaking stage (1987) was made by Yossi Shiloah, an immigrant from Kurdistan. Shiloah, a graduate of the Beit Zvi theatre school, was at the time a popular actor specializing in stereotypical roles depicting Oriental Jews as ludicrous and cunning in popular Israeli slapstick comedies, and he wanted to prove himself a serious actor. His choice of Palestinian literature was due to his political involvement in acts of protest against the violation of Arab rights in Israel and the Territories. Adapting works of high literary merit by Mahmoud Darwish, Sameeh el-Qasem, Ghassan Kanafani and Fadwah Tuqan for stage performance therefore fit both his career and his political aspirations. A Journey (1987), a theatrical prose and poetry collage, included both texts adapted from written translations (e.g. Men in the Sun) while other works (e.g. fragments of Tuqan's diary) were translated by the present writer at the actor's own expense. Moshe Kaleef, a fringe director, 
directed the collage while Tayseer Elias, graduate of the Jerusalem Music Academy, accompanied it on his oud.

Shiloah produced his play in 1987 in order to commemorate 20 years of Israeli conquest of the Territories (1967-1987) selecting texts that emphasized Palestinian suffering and pointing out that there were human beings on both sides of the Israeli-Palestinian conflict (from an interview with Shiloah, Yediot Aharonot, 8.7.87 and his words in the theatre programme). But like the Newe Tzedeq theatre group, he used the image of the wandering Jew as a sufferer with no place of his own except as a mortal sinner to balance the strong pro-Palestinian tone of his play.

All the money necessary to produce The Journey came out of Shiloah's own pocket and his sole support came from two small fringe theatres - Newe Zedeq Theatre provided him with rehearsal space and Beit Lyesin theatre let him perform the play in its smaller Tel Aviv auditorium. When, however, Shiloah applied to Omanut la-'Am [= Art for the People], a governmental institution that sponsors artistic activities in the Israeli periphery to have his play included in their list of subsidised cultural activites he was rejected because of the political message of The Journey.

Both Shiloah's acting and the humanistic contents of his play were highly acclaimed by Israeli Jewish critics. The Journey reminded them of the suffering of the Jewish refugee of the distant past, not mentioned in the texts, as much as of the Palestinian refugee of the proximate past with whom the texts were actually concerned. One critic, actor Rafi Keinan, praised the ability of Shiloah, an immigrant from Kurdistan, to identify with the plight of the Palestinian refugee uprooted from his land (Ha'aretz, 10.1.87). Since warm praise still brought no financial support Shiloah was forced to give up and was so discouraged by his financial failure that he left Israel for a few years.

Since then, for the last 12 years, no Palestinian play or adaptation of a literary text has been performed in Hebrew translation. Major changes in Israeli public opinion resulting from progress in the 
Peace process have failed to be reflected by the theatre and even Israeli Hebrew fringe theatres did not continue what they started in the $1980 \mathrm{~s}^{10}$.

\section{Conclusion}

The publication of translations of Palestinian literature into Hebrew in all different frameworks, has heavily depended on political circumstances and on both the initiatives and efforts of individual translators and editors, actors and directors, without which it would not have existed at all. The marked positive change in the attitude of Israeli Hebrew culture toward the Palestinians and their plight indeed gradually made these translations easier to publish and better received. However, they still remain one-time individual ventures of limited influence and are still marginal with respect to the Israeli Hebrew cultural polysystem, as distinct from their relatively high position within the extremely marginal subsystem of translations from Arabic into Hebrew as a whole.

When future peace brings a growing normalization of Israeli-Palestinian relations, mutual literary translation may play an important role in the attempt to turn a long and painful conflict into a new story of good neighbourhood. It will doubtless be worth studying the subject of the present paper again in 10 years time in order to see whether

\footnotetext{
${ }^{10}$ As the present article was being completed the present writer was asked by the Cameri, the Tel Aviv municipal theatre, to select and translate seven plays from Arabic into Hebrew to be read as a special one-time theatrical event. One of those, approved by the special project repertoire committee is to be the Palestinian play The Birds Build Their Nest between her Toes by poet-playwright Mu'eem Bseeso from Gazza. This play poetically depicts Palestine as a bedridden paralyzed woman who, after being grossly maltreated and abused by her caretakers, gets up and starts walking on her own two feet.

In terms of Polysystem theory, this event signifies an important step forward from the margin towards the centre of Israeli Jewish theatrical activity, this being the first performance in a mainstream theatre. It should be noted, however, that the theatre has chosen the safe and less expensive way of reading the plays rather than performing them, which, on the other hand, will expose the audience to seven plays at a time rather than just one.
} 
and how politics continue to act as the main catalyst of this translation activity.

Beit Berl College, Israel

\section{References}

AMIT-KOCHAVI, Hannah (1996). "Israeli Arabic Literature in Hebrew Translation - Initiation, Dissemination and Reception". The Translator, vol. $2, n^{\circ} 1$, pp. 27-44.

- (1999). Translations of Arabic Literature into Hebrew: Their Historical and Cultural Background and Their Reception by the Target Culture. Ph.D. thesis submitted to the Senate of Tel Aviv University [in Hebrew with an English abstract].

ASHRAWI, Hanan (1976). Contemporary Palestinian Literature under Occupation. Bir Zeit, Bir Zeit University.

BAHAT, Dan (1972). "Anahnu ba-Mizrah ve-Libenu be-Sof Ma'arav" [We're in the East while our Heart is in the remote West]. Ofeq, $\mathrm{n}^{\circ} 2, \mathrm{pp}$. 183-192. [in Hebrew]

BALLAS, Shimon (1970). Ha-Sifrut ha-'Arvit be-Tzel ha-Milhamah [Arab Literature under the Shadow of War]. Tel-Aviv, Ofaqim, Am Oved. [in Hebrew]

BEN EZER, Ehud (ed.) (1992). Be-Moledet ha-Ga'agu'im ha-Menugadim. Ha'Arvi ba-Sifrut ha-'Ivrit. Mivhar Sippurim [In the Homeland of Contradictory Longing. The Arab in Hebrew Literature. An Anthology]. Tel Aviv, Zmorah Bitan. [in Hebrew]

COHEN, Adir (1985). Panim Mekhoarot ba-Mar'ah: Hishtaqfut ha-Sikhsukh ha-Yehudi-'Aravi be-Sifrut ha-Yeladim ha-'Ivrit [An Ugly Face in the Mirror: the Reflection of the Jewish-Arab Conflict in Hebrew Children's Literature]. Tel Aviv, Reshafim. [in Hebrew] 
DAVID, Yona (ed.) (1959). Et Asher Baharti ba-Shira [My Own Poetry Anthology]. Tel Aviv, Hadar Publishing house. [in Hebrew]

DOMB, Risa (1982). The Arab in Hebrew Prose, 1911-1948. London, Vallentine Mitchell.

ELAD-BOUSKILA, Ami (1999). Modern Palestinian Literature and Culture. London* Portland Or, Frank Cass.

ESHEL, Ruth (1991). Lirqod im he-Halom, Reshit ha-Mahol ha-Omanuti be-Eretz Yisrael 1920-1964 [Dancing with your Dream, the Advent of Artistic Dance in Palestine 1920-1964]. Tel Aviv, Sifriyat Poalim. [in Hebrew]

EVEN-ZOHAR, Itamar (1990). "Polysystem Studies", Poetics Today vol. $11, \mathrm{n}^{\circ} 1$. Tel Aviv, The Porter Institute for Poetics and Semiotics.

- (forthcoming). Papers in Polysystems of Culture.

GORNY, Yoseph (1985). Ha-She'elah ha-Arvit ve ha-Be'ayah ha-Yehudit [ The Arab Question and the Jewish Problem]. Tel Aviv, Am Oved [in Hebrew]

HORROWITZ, Dan and Moshe Lisak (1986). Mi-Yeshuv li-Medinah, Yehudei Eretz-Yisrael bi-Tequfat ha-Mandat ha-Briti ke-Kehilah Politit [From Community to State - The Jews in Palestine as a Political Community during the British Mandate]. Tel Aviv, Am Oved [in Hebrew].

HORROWITZ, Dani (1993). Kemo Gesher Taqu'a. Sihot im ha-Sahkanim Muhammad Bakri, Salwah Naqqarah, Makram Hoory, Khawlah Hajj veSaleem 'Daw [Like a Stuck Bridge. Conversations with Actors Muhammad Bakri, Salwah Naqaarah, Makram Hoory, Khawlah Hajj and Saleem 'Daw]. Beit Berl, The Centre for the Study of Israeli Arab Society and Ha-Kibbutz ha-Meuchad Publishing house. [in Hebrew]

KINBERG, Naphtali, and Rafael Talmon (1994). "Learning of Arabic by Jews and the Use of Hebrew among Arabs in Israel". JOAL, XX, 1\&2, pp. 37-54. 
LANDAU, Jacob M. (ed.) (1961). Horaat ha-'Arvit ke-Safah Zarah [Teaching Arabic as a Foreign Language]. Jerusalem, The Hebrew University School of Education and the Ministry of Education and Culture. [in Hebrew]

MOREH, Shmuel and Mahmoud 'Abbasi (eds) (1987). Taraajim wa-Aathar fi al-Adab al-'Arabi fi Israeel [Biographies and Bibliographies in Arabic Literature in Israel (1948-1986)]. The Public Council for Culture and Arts, Arabic Culture Department, Jerusalem, The Harry S. Truman Research Institute, the Hebrew University; Shfaram, Al-Mashreq Publishing house. [in Arabic]

MORRIS, Benny (1991). Leidatah Shel Be'ayat ha-Plitim ha-'Falastinim 1947-1949 [The Birth of the Palestinian Refugee Problem 1947-1949]. Tel Aviv, Am Oved. [in Hebrew]

NIR, Yishayahu (1985). The Bible and the Image, the History of Photography in the Holy Land 1839-1899. Philadelphia, University of Pennsylvania Press.

ORIAN, Dan (1996). Dmut ha-'Arvi ba-Teatron ha-Yisraeli [The Arab Figure in Israeli Theatre], No place indicated, Or Am. [in Hebrew]

PELED, Mattityahu (1982). "Annals of Doom: Palestinian Literature 1917-1948", Arabica, vol. XXIX, n² 2, pp. 141-183.

RAMRAS-RAUCH, Gila (1989). The Arab in Israeli Literature. Bloomington and Indianapolis, Indiana University Press.

SAID, Edward (1978). Orientalism. New York, Pantheon Books.

- (1993). Culture and Imperialism. New York, Knopf.

SARIG, Lea (1987). Some Linguistic Problems in Translations of Modern Arabic Prose into Hebrew. [Ph.D. thesis submitted to the Senate of Bar Ilan University, in Hebrew]

- (1992). "On Two Markers of Arabic-Hebrew Prose Translation", Target, vol. 4, $\mathrm{n}^{\circ} 2$, pp. 209-222. 
SHAVIT, Zohar (1986). Poetics of Children's Literature. Georgia, University of Georgia Press.

SHOHAT, Ella (1991). Ha-Kolnoa ha-Yisraeli, Historia ve-Ideologia, [Israeli Cinema, Its History and Ideology]. Tel Aviv, Brerot. [in Hebrew]

SOMEKH, Sasson (1999). "Reconciling Two Great Loves: the First Jewish-Arab Literary Encounter in Israel", Israel Studies, vol. 4, ${ }^{\circ} 1$, pp. $1-21$.

YINON, Avraham (1965). "Kamah Nos'ei Moqed ba-Sifrut shel 'Arviyei Yisrael" [Several Central Topics in Israeli Arab Literature], Hamizrah He-Hadash, $\mathrm{n}^{\circ}$ 15, pp. 57-84. [in Hebrew]

- (1966). "Nos'im Hevratiyim be-Sifrut 'Arviyei Yisrael" [Social Topics in Israeli Arab Literature], Hamizrah He-Hadash, $\mathrm{n}^{\circ} 16$, pp. 349-380. [in Hebrew]

YONAI, Yoseph (ed.) (1992). 'Arvit be-Vatei Sefer 'Ivriyim [Arabic (Learning) at Hebrew-speaking Schools]. Jerusalem, The Ministry of Education and Culture, the Historical Branch. [in Hebrew]

ZALMONA, Yigal and Tamar Manor-Friedman (eds.) (1998). To the East: Orientalism in the Arts in Israel, Jerusalem: the Israel Museum. [in Hebrew, with an English introduction and captions]

ABSTRACT : Hebrew Translations of Palestinian Literature - From Total Denial to Partial Recognition - The present paper describes Hebrew translations of Palestinian literature written in the West Bank and Gazza Strip and the Palestinian diaspora and their gradual progress from total denial to partial recognition within the Hebrew cultural polysystem. The preface is followed by three sections: the attitude of Israeli Hebrew culture to translations from Palestinian literatures from the 1950s up to the present against the historical background of the Israeli-Palestinian conflict; the publication of translations of particular works by particular writers; Hebrew stage performances of adaptations of translated Palestinian literature. 
RÉSUMÉ : Traductions hébraïques d'œuvres palestiniennes - de la dénégation totale à une reconnaissance partielle - Le présent article retrace les traductions en hébreu d'œuvres palestiniennes émanant de Cisjordanie, de la bande de Gaza et de la diaspora palestinienne. Il explore également le passage graduel de la dénégation totale à une reconnaissance partielle de ces écrits au cœur du polysystème culturel hébreu.

L'introduction est suivie de trois parties. La première examine la position de la culture hébraique israélienne face aux traductions d'œuvres palestiniennes depuis les années 50, dans le contexte historique du conflit israélo-palestinien. La deuxième porte sur la publication des traductions de certaines œuvres par quelques auteurs. Finalement, la dernière étudie les représentations théâtrales en hébreu d'adaptations d'œuvres palestiniennes traduites.

Keywords : politics, intercultural, ideology, history, Arabic.

Mots-clés : politique, interculturel, idéologie, histoire, Arabe.

Dr. Hannah Amit-Kochavi : Beit Berl College Israel, 29 Trumpeldor St. Haifa, Israel 32851.

E-MAIL : amitkoch@netvision.net.il 